\title{
Performance Appraisal System and Business Performance: An Empirical Study in Sri Lankan Apparel Industry
}

\author{
M.A.M. Hussain Ali \\ Faculty of Management and Commerce \\ South Eastern University of Sri Lanka \\ hussainm@seu.ac.lk \\ And \\ H.H.D.N.P.Opatha \\ Department of Human Resource Management \\ University of Sri Jayewardenepura \\ Opatha@sjp.ac.lk
}

\begin{abstract}
The objectives of this study were to investigate whether Performance Appraisal (PA) significantly relates to business performance in Sri Lankan apparel firms; to find out whether a significant difference exists between large apparel firms and non-large apparel firms with regard to perceived quality of PA and to reveal whether a significant difference exists between large apparel firms and non-large apparel firms with regard to business performance. Three hypotheses were formulated using deductive approach. The study was conducted by using a stratified random sample of 274 apparel firms in Sri Lanka. Type of investigation was correlational and it was cross-sectional in time horizon. The unit of analysis was organisational level: each firm. General Manager or Human Resource Manager served as the respondent on behalf of the firm. Measures of the study were of good quality after assuring reliability and validity. Data were possible to be collected from 68 apparel firms-18 non-large firms and 50 large firms. In order to test the first that was concerned with relationship between perceived systematic use of performance appraisal system of a firm and perceived degree of business performance the Pearson Product-Moment Correlation technique was applied. The second hypothesis and third hypothesis were concerned with difference between large apparel firms and non-large apparel firms with regard to perceived quality of $P A$ and perceived degree of business performance respectively and Independent Sample T test was the appropriate technique to test the validity of the two hypotheses. The results of the study showed a significant and positive relationship between perceived systematic use of PA system and perceived degree of business performance of apparel firms in Sri Lanka. Found relationship was strong (correlation coefficient was .826 that was significant at .0005) implying that an apparel firm, though it is large or non-large, should adopt a more systematic PA system so as to improve its business performance. However the study revealed no statistical evidence to claim that the degree of perceived quality of PA of large apparel firms is significantly different from that of non-large apparel firms and that
\end{abstract}


the perceived degree of business performance of large apparel firms is significantly different from that of non-large apparel firms.

Key words: Business Performance, Performance Appraisal, Sri Lankan Apparel Industry

\section{Introduction}

Socio-economic development of Sri Lanka heavily depends on success and progress of success of organizations, and Human Resource Management (HRM), which is one of the most important functional fields of Organizational Management, is a sine qua non of success and progress of success of organizations at the micro level and socio-economic development of Sri Lanka in a competitive world market at the macro level (Serasinghe and Opatha, 2007). Performance Appraisal (PA) is one of the most important functions of HRM and the term 'Performance Appraisal' is concerned with identifying, measuring, influencing and developing job performance of employees in the organization in relation to the set norms and standards for a particular period of time in order to achieve various purposes (Opatha, 2009). Employees are required to generate a total commitment to desired standards of job performance and improved job performance for sustaining profitable growth for the organization and long-term value creation for the customers. PA measures how well and how far employees are performing their jobs within the period being considered for enhancing human performance and business performance of the organization.

Business performance is the major concern of managers as it indicates success and progress of success of the organisation. It is about how well and how far the organisation has carried out its activities within a certain period of time. It is about how successful the organisation is within a period of time being considered. An organisation that wants to be successful should achieve a high level of business performance. There are many functions to be carried out in order to achieve expected or higher (compared with previous year or the past) business performance of an organisation and, one important function of HRM is PA. This study was carried out in firms which are engaged in Sri Lankan Apparel Industry.

The Sri Lankan Apparel Industry is of considerable importance to the manufacturing industries in terms of output and employment (Master Plan Study/ Apparel Industry, UNIDO, 2000). One of the most important factors which have contributed to the rapid development of the apparel industry in Sri Lanka has been highly trainable, skilled and literate workforce (Sri Lanka Garment, 2002). In a labour intensive industry such as the apparel industry developing human resources is a fundamental requirement for the development of the industry (Sri Lanka Garments, 2001). Among the critical success factors of the competitiveness of the apparel industry the human resource management is one of the factors (Master Plan Study - Apparel Industry, UNIDO, 2000). As PA is one of the major functions of human resource management, PA's contribution to the success or business performance of apparel industry warrants to be studied for future serious adaptation of PA systems. 
There are theoretical explanations or arguments (Youdt at al, 1996; Arthur, 1994; Huselid, 1995; Huselid \& Becker, 1996; Huselid et al, 1997; Huselid, 1995; Becker \& Gerhart, 1996; Delaney \& Huselid, 1996; Berman et al, 1999; Grote, 2000; Pettijohn \& Amico, 2001; McAfee \& Champagne, 1993) in respect of the relationship between performance appraisal and business performance. There are very few studies carried out in Sri Lanka in respect of employee performance evaluation including an in-depth research carried out by one of the researchers (Opatha, 1992 as in Opatha, 2003) focusing on employee performance appraisal practices of selected state corporations in Sri Lanka and another empirical study was done focusing on employee performance evaluation systems of selected public quoted manufacturing firms in Sri Lanka (Opatha, 2003). It is possible to note that no prior empirical studies were carried out on PA and its relationship with business performance in Sri Lanka. It seems that there is a gap in the empirical knowledge available in Sri Lankan context about testing the relationship between PA and business performance. This paper focuses on addressing the following three research questions:

1. Is there a significant relationship between PA and business performance in firms engaged in Sri Lankan apparel industry?

2. Is there a significant difference between large apparel firms and non-large apparel firms with regard to perceived quality of PA?

3. Is there a significant difference between large apparel firms and non-large apparel firms with regard to business performance?

The objectives of the paper are to investigate whether PA significantly relates to business performance in Sri Lankan apparel firms; to find out whether a significant difference exists between large apparel firms and non-large apparel firms with regard to perceived quality of PA and to reveal whether a significant difference exists between large apparel firms and non-large apparel firms with regard to business performance.

\section{Research Framework}

Performance Appraisal has several associated terms such as merit rating, employee rating, employee evaluation, performance review, performance evaluation, personnel appraisal, personnel review, progress report, service rating, effectiveness report, confidential report, annual report, increment report, and competency report (Beach, 1980; Graham and Bennett, 1998; Mathis and Jackson, 2000; and Opatha, 2002). However for this study the term 'Performance Appraisal' is used. It is about systematic use of performance appraisal practices or quality of the PA system. The working definition of PA is perceived degree to which performance appraisal system has attributes those are right for fair and accurate evaluation of employee job performance. The attributes comprise nine features such as PA Objectives; PA Policies; PA Criteria and Standards; PA Form and Procedure; Training of Appraisers; Feedback Discussion; Procedure for Ensuring Accurate Implementation; Make Decisions and Store them; and Review and Renewal (Beach, 1980; Graham and Bennett, 1998; Mathis and Jackson, 2000; Opatha, 2002; and Dessler, 2007). These aspects are perceived as reflective of the realities of a PA system, and therefore the 
nine attributes are required to examine systematic use or quality of a PA system. The greater the attributes existing in the system the higher the quality of the system is.

Business Performance has two associated terms such as performances and organizational performance (Said et al, 2006). However for this study the term 'Business Performance' is used. For the working purpose it is defined as perceived degree of how successful a firm was during the last three years in relation to certain business aspects of success. This definition is regarded as the working definition of business performance for this study and it has three characteristics that are as follows:

1. It is a perceived success as measurement is subjective.

2. It is within three years by recognizing that success can be achieved within a relatively long period of time.

3. It is in respect of certain business aspects of success by recognizing that the concept of business performance is multifaceted.

Aspects of success include Return on Sales; Revenue; Return on Assets; Cash Flow; Customer Satisfaction; Responsiveness/Speed; Corporate Image; Market Share; Number of Customer Complaints resolved; Quality; Cost per Unit, Productivity; Employee Morale; Human Resource Development; Speed of Launching New Product; Research and Development; Technology Innovation; and Learning Organisation. These aspects are grouped into four perspectives which are financial, customer, internal efficiency and innovation. These aspects were based on the model developed by Chandrachai (2001).

Success of an organization largely depends on how effectively employees perform their jobs (Heneman 111 and Schwab, 1982). Employee PA monitors how far and how well employees perform their jobs. PA identifies, measures and develops job performance of employees in an organization and therefore it is a planning technique of employee performance and a controlling technique of employee performance as well. Employees in a firm are required to generate a total commitment to desired standards of performance to achieve a competitive advantage and improved performance for sustaining that competitive advantage at least for a prolonged period of time, if not forever. In view of Judge and Ferris (1993), perhaps there is no more important human resources system in organizations other than performance appraisal and ratings of employees' performance represent critical decisions that are key influences on a variety of subsequent human resources actions and outcomes. Effective PA drives employees in a firm to produce excellent standards of performance and even beyond the excellent (exceptional) standards of performance. Serious use of result-oriented performance appraisal criteria, such as quality of work, quantity of work, and behaviour-oriented criteria such as attendance, punctuality, availability will lead to maintain and increase the employee productivity, development, quality etc. Employee effects will lead to maintaining and increasing business performance. Because many managers conduct performance appraisal, it seems logical that identifying the characteristics of the appraisal process that yield the greatest organizational benefits could be of value (Pettijohn and Amico, 2001). By having employees and managers work together on developmental plans which are consistent with corporate objectives and on individualized PA criteria, an organization can 
potentially improve both morale and productivity (McAfee and Champagne, 1993). Hence, these arguments lead to a hypothesis as follows:

Hypothesis 1: Perceived systematic use of performance appraisal system of a firm is significantly and positively related to its business performance.

There is no empirical evidence to know that a significant difference exists between large apparel firms and non-large apparel firms operating in Sri Lanka with regard to perceived quality of PA. However, a recent study (Serasinghe and Opatha, 2007) revealed that a significant difference exists between local listed firms in Sri Lanka and multinational firms operating in Sri Lanka with regard to systematic use of HRM practices including performance appraisal. Wijewardena et al (2000) noted that the importance of efficient management seems to has been rated more highly by large firms than small and mediumsize firms. It is argued that compared with non-large firms, large firms have a higher number of employees, a better financial stability, and a separate department for HRM under the leadership of a professional manager called HR Manager. Hence it is more likely that large apparel firms have more sophisticated and formal performance evaluation systems compared with those of non-large apparel firms. Hence, based on these arguments, the second hypothesis of this study is:

Hypothesis 2: There is a significant difference between large apparel firms and non-large apparel firms operating in Sri Lanka with regard to perceived quality of PA.

Generally large apparel firms are larger than non-large apparel firms in terms of market size, profitability, financial stability, and ability of getting financial aids. Also large apparel firms are higher than non-large apparel firms in terms of age generally. Lager apparel firms have a better possibility of applying sophisticated management techniques than non-large apparel firms have. More likely large apparel firms are greater than nonlarge apparel firms in terms of learning through experience and they are better financially to utilize more qualified personnel in all the fields of Business Management. The above arguments lead to formulate a hypothesis that is stated below:

Hypothesis 3: There is a significant difference between large apparel firms and non-large apparel firms in Sri Lanka in respect of perceived degree of business performance.

Figure 1 presents the relevant schematic diagram. Systematic use of performance appraisal is labeled as the independent variable and perceived business performance is labeled as the dependent variable. Large apparel firms and non-large apparel firms are considered as two independent groups for the study.

\section{Study Design}

\section{Method}

The researchers were interested in investigating whether PA relates to business performance of apparel firms in Sri Lanka and whether there are differences between large apparel firms and non-large apparel firms with regard to systematic use of performance appraisal and perceived degree of business performance. There was no 
intention of establishing definite cause $\rightarrow$ effect relationship between the two variables. The type of investigation of this study was, therefore, correlational and differential rather than causal. Because this study attempted to analyse the relationship between the dependent variable and the independent variable, this study was analytical in nature or purpose. The study was conducted in the natural environment of the selected apparel manufacturing firms and the researchers' interference was minimal with the normal flow of events. As the data collection was done for this study within a particular time period and there was no subsequent extension of the research contemplated, the study was crosssectional in nature (Sekaran, 2004).

\section{Figure: 1 Schematic Diagram of the Research Framework}

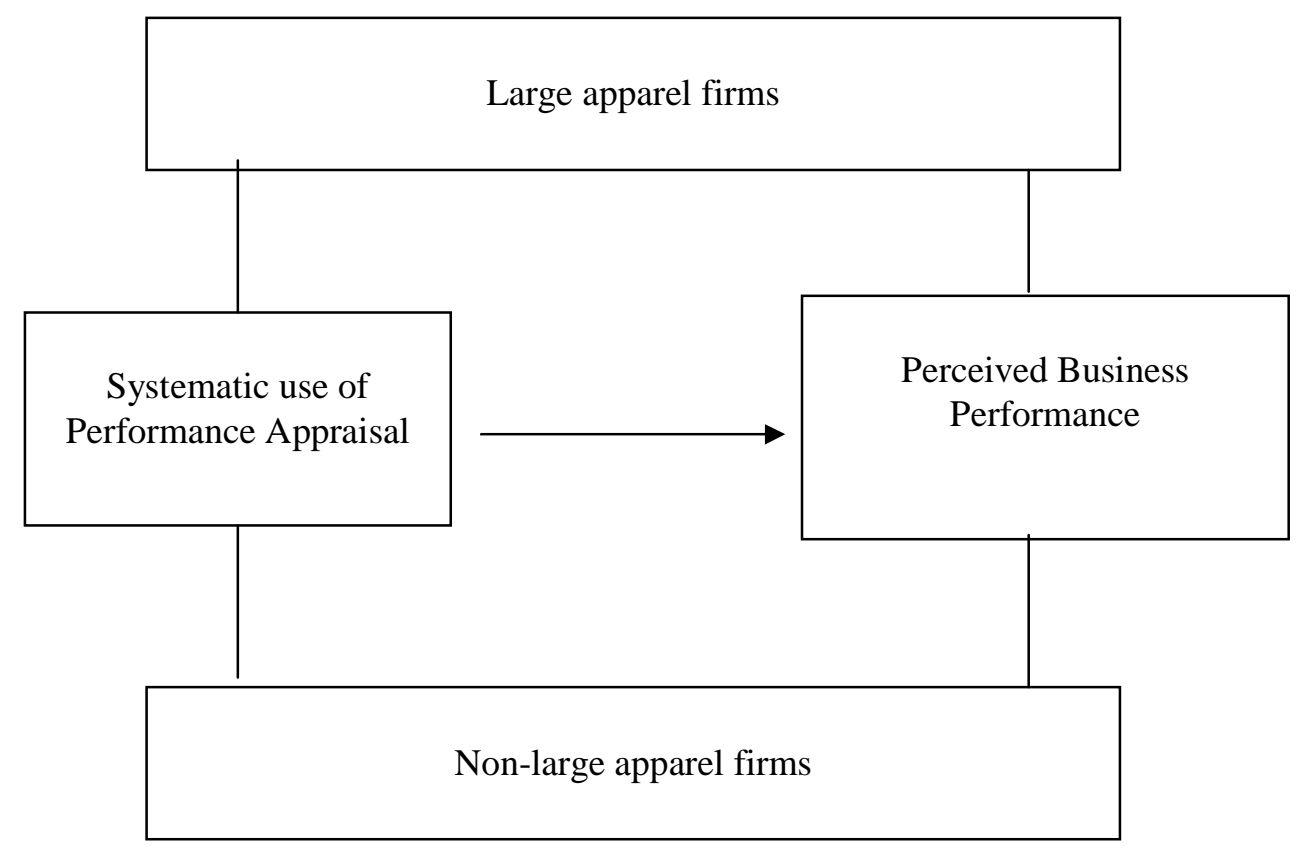

Population of this study covered all the apparel firms in Sri Lanka and there were 830 firms (Sri Lankan Apparel Industry: 5 Year Strategy as in Lankathilake, 2003). These firms were classified into three levels such as small, medium, and large manufacturers in the apparel industry. There were 157 small, 438 medium and 235 large manufacturers in the apparel industry in Sri Lanka (Lankathilake, 2003). Stratified random sampling method was applied and the following Table gives the sample information.

Table: 1 Stratified Random Sampling

\begin{tabular}{|c|l|l|l|c|}
\hline \multicolumn{2}{|c|}{ Category } & $\begin{array}{l}\text { Number of } \\
\text { Manufacturers }\end{array}$ & $\begin{array}{l}\text { Random } \\
\text { Selection }\end{array}$ & $\begin{array}{l}\text { Manufacturers } \\
\text { in Sample }\end{array}$ \\
\hline \multirow{3}{*}{ Not Large } & $\begin{array}{l}\text { Small (1-100 } \\
\text { employees) }\end{array}$ & $\mathrm{N}=157$ & $33 \%$ & \multirow{2}{*}{$\mathrm{n}=196$} \\
\cline { 2 - 4 } & $\begin{array}{l}\text { Medium (101-250 } \\
\text { employees) }\end{array}$ & $\mathrm{N}=438$ & $33 \%$ & \\
\hline
\end{tabular}


Sri Lankan Journal of Human Resource Management

\begin{tabular}{|c|l|l|l|c|}
\hline Large & $\begin{array}{l}\text { Large (over 251 } \\
\text { employees) }\end{array}$ & $\mathrm{N}=235$ & $33 \%$ & $\mathrm{n}=78$ \\
\hline & Population & $\mathrm{N}=830$ & Sample & $\mathrm{n}=274$ \\
\hline
\end{tabular}

Selected sample size for the study was $274(n=274)$ as shown in the above Table which accounts to a random selection of $33 \%$ of the population $(\mathrm{N}=830)$ in order to make the sample more representative. The $33 \%$ sample was drawn from each category of the apparel industry by using systematic sampling. In a systematic sampling, every $k$ th element in the population is sampled, beginning with a random start of an element in the range of 1 to $k$ (Cooper and Schindler, 2003). After deciding the sample size the sample ratio was obtained through dividing the population by the desired sample $(830 / 274=$ 3.03). Thus, having decided on a starting point on a random basis every 3rd number (name of the firm) was picked and the sample of 274 out of 830 manufacturers in the apparel industry was taken. Accordingly, the sample consists of 196 non-large apparel firms and 78 large apparel firms. Roscoe ( 1975) as in Sekaran (2004) points out that the sample sizes larger than 30 and less than 500 are appropriate for most research and where samples are to be broken into sub samples; a minimum sample size of 30 for each category is necessary. These sample organizations were selected from the registered organizations in the Board of Investment of Sri Lanka and the Ministry of Industrial Development.

A structured questionnaire was developed and distributed among the firms under the sample. Unit of analysis was organizational level: each firm. On behalf of the firm the General Manager or HR Manager served as the respondent. It was possible to collect 68 questionnaires from 68 apparel firms-18 non-large firms and 50 large firms.

\section{Measures}

Performance Appraisal: The perceived degree of PA in an organization was operationalised into nine dimensions i.e., Objectives, Policies, Criteria and Standards, Appraisal Form and Procedure, Training of Appraisers, Feedback Discussion Interview, Procedure for Ensuring Accurate Implementation, Make Decisions and Store, and Review and Renewal (Kossek and Label, 2001; Opatha, 2002; Mangaraj, 1998; Bolton, 1999; French, 1997; and Bernardin and Russell, 1998). Indicators/elements used to measure these dimensions with relevant sources from which they were adapted are: (1) Objectives: Adequacy of administrative purposes and Adequacy of development purposes (Opatha, 2002; McAfee \& Champagne, 1993); (2) Policies: Soundness of on whom, Soundness of when, Soundness of who, and Soundness of how often (Glueck, 1979 as in Opatha, 2002; Towers,2000; Opatha, 2002; French, 1997; Ferris, et al., 1998; Beach, 1980; Mathis and Jackson, 2000; Mithani and Opatha, 2000; Kaplan, 1993 as in Ferris et al, 1998; and Glueck,1978); (3) Criteria and Standards : Adequacy of criteria, definitions of criteria, and objectivity and quality of standards(Mathis and Jackson, 2000; Ivancevich, 1998; Glueck, 1978; Opatha, 2002; and Cascio, 1998); (4) Design Forms and Procedure: Availability of separate appraisal forms and procedure, and Appropriateness of the appraisal form (Opatha, 2002; Opatha, 2003); (5) Train Evaluators: Availability of training, Appropriateness of the training method, Availability of training manual, and Quality of training program content (Opatha, 2002; Ferris et al., 1998; Tyson and York, 
2000; and French, 1997); (6) Feedback: Find out about the availability of discussion, appropriateness of discussion, and adequacy of expected behaviours (Ferris et al., 1998; Nickels et al.,1999; Bernardin and Russell, 1998; Opatha, 2002; Cushway, 1999; Towers, 2000; Rue and Byars, 1992 as in Opatha, 2002; Bolton, 1999; Dessler, 1997; Walker, 1992; and Goodale, 1992 as in Opatha, 2002); (7) Appraisal (Accurate Implementation): Use of responsibility practices for ensuring and Use of other practices (Bernardin and Russell, 1998; Opatha, 1992); (8) Decisions \& Store: Responsibility for final decisions and Systematically storage of data (Opatha, 2002); (9) Review and Renewal: Availability of review and renewal and Continuity of review and renewal (Opatha, 2002; Bernardin and Russell,1998). Weightages or values of 5,4,3,2 and 1 were given to responses taking the nature of the response categories of the question items into account. For an example that describes and explains how measuring and giving scores on a dimension ('Policies') were done, see Appendix 1.

Business Performance: The perceived degree of how successful a firm was during the last three years was operationalized into four dimensions such as financial perspective, customer perspective, internal efficiency and innovation. By following the model developed by Chandrachai (2001), dimensions were operationalized into several elements. Financial perspective had five elements such as return on sales, revenue, return on equity, return on assets and cash flow. There were five elements of customer perspective including customer satisfaction, responsiveness/speed, corporate image, market share, and number of customer complaints resolved. Dimension of internal efficiency had five elements, i.e., quality, cost per unit, productivity, employee morale, and human resource development. Dimension of innovation was operationalized into four elements such as speed of launching new product, research and development, technology innovation and learning organisation. Question items were developed to tap elements of each dimension and the responses to the questions were elicited on a 5-point scale of 'very high extent, high extent, moderate extent, low extent, and very low extent'. Weightages or values of 5,4,3,2 and 1 were given to these responses.

\section{Validity and Reliability}

The reliability has two aspects, i.e. stability (ability to produce consistent results over time despite uncontrollable testing conditions or the state of the respondent) and consistency (homogeneity of the items in the instrument tapping the construct) (Sekaran, 1999 as in Opatha, 2002). A measure is reliable to the degree that it supplies consistent results (Cooper and Schindler, 2003). The test-retest was done for estimating external reliability (stability aspect) by using 12 managers from twelve apparel organizations with a four-week time interval between the two administrations. The test-retest coefficients of the instruments measuring performance appraisal system and business performance were 0.97 and 0.89 respectively suggesting that each instrument possesses a high degree of test-retest reliability. This suggested that there was a strong consistency of responses between two administrations. The Cronbach's Coefficient Alpha is used to test the degree of the interitem consistency of an instrument (Walsh, 1995: and Sekaran, 1999 as in Opatha, 2003). The Cronbach's alphas for PAS and business performance were 0.9544 and 0.8929 respectively suggesting a good interitem reliability. 
The content validity of a measuring instrument (the composite of measurement scales) is the extent to which it provides adequate coverage of the investigative questions guiding the study (Cooper and Schindler, 2003). There are three main kinds of evidence in support of content validity and they are: (1) the judgment of those who construct the instrument or other experts familiar with the subject area; (2) detailed definition or conceptualisation and operationalisation of the behavioral domain or universe of interest; and (3) indirect way-high internal consistency reliability (Walsh and Betz, 1995; and Sekaran, 1999). As far as the two variables (constructs) under this study are concerned, meeting of these three requirements was done satisfactorily assuring content validity.

\section{Techniques of Data Analysis}

There were three hypotheses of the study. First hypothesis was about relationship between two variables, and hence the Pearson Product-Moment Correlation technique was used. As the second hypothesis was about testing a difference between two groups with regard to one variable, Independent Sample T Test was applied. The same test was applied to testing of the third hypothesis as it was too about testing a difference between two groups regarding one variable. There was a need of exploring the data for normality and linearity, as the correlation test was parametric. It was revealed that exploration of the data met the conditions reasonably.

\section{Results}

The first hypothesis formulated for the study was that perceived systematic use of performance appraisal system of a firm is significantly and positively related to its business performance. The relevant null hypothesis is stated as that there is no relationship between perceived systematic use of performance appraisal system of a firm and its business performance. The appropriate statistical test was Pearson Product Correlation Coefficient in order to test the alternative hypothesis. Desired level of significant level was 0.05. One-tailed test was used as the formulated alternative hypothesis had been directional. Following Table presents the results of the correlation test.

\section{Table: 2 Correlation between Performance Appraisal System and Business Performance of the Firm}

\begin{tabular}{l|l} 
Pearson correlation coefficient & 0.826 \\
Significant (One-tailed) & 0.000 \\
N & 68 \\
\hline
\end{tabular}

According to the Table the found Pearson Correlation Coefficient is 0.826 suggesting that there is a strong positive relationship between the performance appraisal system of the firm and business performance of the firm. As the significant value $(0.000)$ is smaller than the desire level of significance $(0.005)$, the found correlation coefficient $(0.826)$ is statistically significant. Hence alternative hypothesis can be accepted while rejecting the null hypothesis. Therefore, there is statistical evidence to claim that there is a significant relationship between perceived systematic use of performance appraisal system of a firm and its business performance. 
The second hypothesis formulated for this study was that there is a significant difference between large apparel firms and non-large apparel firms operating in Sri Lanka with regard to perceived quality of PA. Relevant null hypothesis is that there is no difference between large apparel firms and non-large apparel firms operating in Sri Lanka with regard to perceived quality of PA. In order to perform testing the hypothesis the appropriate statistical technique was Interdependent Sample T Test and the desire level of significance is 0.05 (95\% confident level). As the alternative hypothesis had been a nondirectional one, two-tail test was appropriate and therefore applied. The following Table shows the results of the independent sample test.

Table: 3 Independent Sample T Test of Difference between Large Firms and NonLarge Firms regarding Perceived Quality of PA

\begin{tabular}{|l|l|}
\hline & Value \\
Mean - Large apparel firms & 3.3000 \\
Mean - Non-Large apparel firms & 2.9444 \\
$\mathrm{t}$ (Equal variances assumed) & -1.363 \\
$\mathrm{t}$ (Equal variances not assumed) & -1.226 \\
Mean difference & .3556 \\
df (degree of freedom) & 66 \\
Sig (2-tailed) & 0.178 \\
\hline
\end{tabular}

When considered the mean value there is a slight difference (.3556) descriptively. It suggests that perceived quality of performance appraisal of large apparel firms is greater than that of non-large apparel firms. Independent Sample T Test was used in order to find out whether this difference is statistically significant or not. Results of the independent sample T Test show that Levene's Test for Equality of Variances is not significant with $\mathrm{F}$ $=.337$ (Sig .563). It is suggested that the null hypothesis that the two samples come from populations with the same variances cannot be rejected. Therefore, $\mathrm{T}$ Test for equal variances assumed was considered (Norusis, 1997). The $\mathrm{T}$ value for equal variances assumed is -1.363 that was not significant at $95 \%$ confident level ( $\mathrm{Sig}=0.178$ is larger than 0.05). Since the $t$ value is statistically insignificant, the relevant null hypothesis cannot be rejected. Therefore the alternative hypothesis is not accepted. Thus there is no statistical evidence to claim that the degree of perceived quality of PA of large apparel firms is significantly different from that of non-large apparel firms.

The third hypothesis formulated for this study was that there is a significant difference between large apparel firms and non-large apparel firms in Sri Lanka in respect of perceived degree of business performance. Relevant null hypothesis is that there is no difference between large apparel firms and non-large apparel firms in Sri Lanka in respect of perceived degree of business performance. The appropriate statistical technique was Interdependent Sample $T$ Test for the purpose of testing the third hypothesis and the desire level of significance was 0.05 (95\% confident level). Hence the 
alternative hypothesis had been a non- directional one, two-tail test was applied. The results of the independent sample test are given in Table 4.

Mean for the perceived degree of business performance of large apparel firms was 3.6400 but that of non-large apparel firms was 3.222. There is a difference (.4178) between the two mean values indicating that perceived degree of business performance of large apparel firms is greater than that of non-large apparel firms. As this is a descriptive difference it needs to be tested statistically. Hence Independent Sample T Test was used in order to find out whether this difference is statistically significant or not.

Table: 3 Independent Sample T Test of Difference between Large Firms and NonLarge Firms regarding Perceived Degree of Business Performance

\begin{tabular}{|l|c|}
\hline & Value \\
Mean - Large apparel firms & 3.6400 \\
Mean - Non-Large apparel firms & 3.2222 \\
$\mathrm{t}$ (Equal variances assumed) & -1.891 \\
$\mathrm{t}$ (Equal variances not assumed) & -1.697 \\
Mean difference & .4178 \\
df (degree of freedom) & 66 \\
Sig (2-tailed) & 0.063 \\
\hline
\end{tabular}

As per the results of the independent sample $\mathrm{T}$ Test, Levene's Test for Equality of Variances is not significant with $\mathrm{F}=2.293$ (Sig .135). Because the null hypothesis that the two samples come from populations with the same variances cannot be rejected, $\mathrm{T}$ Test for equal variances assumed was considered. The $\mathrm{T}$ value for equal variances assumed is -1.891 that was insignificant at $95 \%$ confident level ( $\mathrm{Sig}=0.063$ is larger than $0.05)$. Since the $t$ value is statistically not significant, the relevant null hypothesis cannot be rejected while not accepting the alternative hypothesis. Thus there is no statistical evidence to claim that the perceived degree of business performance of large apparel firms is significantly different from that of non-large apparel firms.

\section{Discussion}

The study found empirical evidence to support the first hypothesis perceived systematic use of performance appraisal system of a firm is significantly and positively related to its business performance. It is more likely that systematic use of performance appraisal system contributes to business performance of a firm positively and significantly. This finding empirically confirms the theoretical arguments given by Huselid et al. (1997), Arthur (1994), Delaney and Huselid (1996), and Huselid (1995). They explained that strong, positive relationships exist between the extent of a firm's adoption of highinvolvement HRM strategies including PA and organizational performance. Implication of the finding is that an apparel firm, though it is large or non-large, should adopt a more systematic performance appraisal system in order to improve its business performance. For the purpose of enhancing quality level of performance appraisal it is essential to work 
on all the nine dimensions, i.e., PA Objectives; PA Policies; PA Criteria and Standards; PA Form and Procedure; Training of Appraisers; Feedback Discussion; Procedure for Ensuring Accurate Implementation; Make Decisions and Store them; and Review and Renewal.

A finding derived from univariate analysis of the data was that quality level of PA in the apparel firms is moderate implying that it needs to be improved to the level that is high. The dimensions such as criteria and standards and procedure for accurate implementation have been rated as high in terms of quality level. Dimensions such as objectives, policies, feedback discussion, and make decisions and store them have been rated as moderate in terms of quality level. Quality levels of three dimensions, i.e., appraisal form and procedure, training of appraisers, and review and renewal were found to be low from the univariate analysis. An implication is that more attention has to be given to improving appraisal form and procedure, training of appraisers and review and renewal dimensions so as to improve quality level of performance appraisal systems of the apparel firms so that they can improve their business performance in a quota-free world market.

The second hypothesis that there is a significant difference between large apparel firms and non-large apparel firms operating in Sri Lanka with regard to perceived quality of PA was not substantiated as far as the data of this study are concerned. The third hypothesis that there is a significant difference between large apparel firms and non-large apparel firms in Sri Lanka in respect of perceived degree of business performance was too rejected according to the results of the study. There were no statistical evidences to substantiate hypothesized differences between large apparel firms and non-large apparel firms with regard to the two variables, i.e., perceived quality of PA and perceived degree of business performance. Findings are somewhat surprising as there were not expected as such. It is more likely that response rate has something to do with the findings. Only 68 firms had responded out of 274 apparel firms' sample. This response number is adequate for testing a hypothesis that is about relationship between two variables. The second and third hypotheses are about a difference between two groups with regard to a variable. Two groups were large apparel firms (50 units) and non-large apparel firms (only 18 units). The difference between the two groups in terms of the number is considerable. Perhaps the smaller number of non-large apparel firms is not matched with the larger number of large apparel firms for the purpose of comparison to find a difference statistically. Hence it is suggested to test the two hypotheses through future studies which will take the two independent samples which are not different in terms of number (exactly same number/size or approximately same).

\section{Conclusion}

The results of the study lead to confirm the prediction made by the researchers regarding a significant and positive relationship between perceived systematic use of performance appraisal and perceived degree of business performance of apparel firms in Sri Lanka. It is more likely that an improvement of the quality of PA system of an apparel firm results in an improvement of business performance of the firm. No statistically significant differences exist between large apparel firms and non-large apparel firms with regard to perceived quality of PA and perceived degree of business performance. It is suggested 
that future studies be carried out to test the validity of the second and third hypotheses by taking the two independent samples (large apparel firms and non-large apparel firms) which are similar exactly or approximately in terms of sample size.

\section{References}

Arthur, J.B. (1994), 'Effects of Human Resource Systems on Manufacturing Performance and Turnover', The Academy of Management Journal, Vol. 37, No. 03, pp. 670 687.

Beach, D.S. (1980), Personnel: The Management of People at Work, $4^{\text {th }}$ ed, New York: Mc Millan Publishing Co. Inc.

Becker, B. and Gerhart, B. (1996), 'The Impact of Human Resource Management as Organizational Performance: Progress and Prospects', Academy of Management Journal, Vol. 39, No. 4, pp. $779-810$.

Berman, S.L., Wicks, A.C., Kotha, S., and Jones, T.M. (1999), 'Does Stakeholder Orientation Matter? The Relationship between Stakeholder Management Models and Firm Financial Performance', Academy of Management Journal, Vol. 42, No. 5, pp. 488-506.

Bernardin, H.J., and Russell, J.E. (1998), Human Resource Management; An Experiential Approach, $2^{\text {nd }}$ ed, New York: Mc Graw Hill, Inc.

Bolton, T. (1999), Human Management: An Introduction, London: Blackwell Publishers.

Cascio, W.F. (1998), Managing Human Resources: Productivity, Quality of Work Life, Profits, $5^{\text {th }}$ ed, Mc Graw Hill, Ins, USA.

Chandrachai, A. (2001), 'Thailand,' Corporate Performance Management, Tokyo: Asian Productivity Organization, pp. 210-243.

Cooper, D.R., and Schindler, P.S. (2003), Business Research Methods, $8^{\text {th }}$ ed, New Delhi: Tata McGraw-Hill Publishing Company Limited.

Cushway, B. (1999), Human Resource Management, Revised ed, London: Kogan Page Limited.

Delaney, J.T., and Huselid, M.A. (1996), 'The Impact of Human Resource Management Practices as Perceptions of Organizational Performance', Academy of Management Journal, Vol. 39. No. 4.

Dessler, G. (1997), Human Resource Management, $7^{\text {th }}$ ed, New Delhi: Prentice Hall of India Private Ltd.

Ferris, G.R., Rosen, S.D., and Barnum, D.T. (1998), The Manual of Human Resource Management, $1^{\text {st }}$ Indian ed, New Delhi: Beacon Books.

French, W. (1997), Human Resource Management, $3^{\text {rd }}$ ed, Chennai: All Indian Publishers and Distributors.

Glueck, W.F. (1978), Personnel: A Diagnostic Approach, Revised Edition, Dallas, Texas: Business Publications, INC.

Godamunne L.K.B., Jayasiri N.W.N., and Somasiri S.E. (1981), Factors that Influence Productivity in Public Enterprises, The Sri Lanka Journal of Management Studies, National Institute of Business Management, No:11. pp.113-141.

Graham, H.T., and Benett, R., (1998), Human Resource Management, ${ }^{\text {th }}$ ed, London: Pitman Publishing.

Grote, D. (2000), 'Performance Appraisal Reappraised', Harvard Business Review, January - February, pp. 21. 
Heneman III, H.G. and Schwab, D.P. (1982), Perspectives on Personnel/Human Resource Management, Homewood: Richard D. IYWIN.

Huselid, M.A. (1995), 'The Impact of Human Resource Management Practices on Turnover, Productivity, and Corporate Financial Performance', Academy of Management Journal, Vol. 39, No. 3, pp. 635-672.

Huselid, M.A., Jackson, S.E., and Schuler, R.S. (1997), 'Technical and Strategic Human Resources Management Effectiveness as Determinants of Firm Performance', Academy of Management Journal, Vol. 40, No. 1, pp. 171 - 188.

Ivancevich, M.J. (1998), Human Resource Management, $7^{\text {th }}$ ed, Boston: Irwin / Mc Graw Hill Companies, Inc.

Judge, T.A. and Ferris, G.R. (1993), Social Context of Performance Evaluation Decisions, Academy of Management, 36:1: pp. 80-105.

Kossek, E.E., and Label, S.A. (2001), Human Resource Management: Transforming The Workplace, $1^{\text {st }}$ Indian ed, New Delhi: Infinity Books.

Lankathilake, S. (2003), Future of the Apparel Industry, News Survey, Central Bank of Sri Lanka, Vol. 24. No. 1. January\& February. pp. 7-12.

Managaraj, S. (1998), 'Performance Appraisal Practices in the Rourkela Steel Plant- A Study', Management \& Labour Studies, Vol. 23, No.2, pp. 319-327.

Master Plan Study for Industrial and Investment Promotion in the Democratic Socialist Republic of Sri Lanka (Phase II) (2000), Appendix-11, UNIDO, Ministry of Industrial Development, Sri Lanka.

Mathis, R.L., and Jackson, J.H. (2000), Human Resource Management, $9^{\text {th }}$ ed. New Delhi: Thopson.

McAfee, R.B. and Champagne, P.J. (1993), 'Performance Management: A strategy for Improving Employee Performance and Productivity', Journal of Managerial Psychology, Vol. 8, No. 05, pp. 24-32.

Mithani, D.M. and Opatha H.H.D.N.P. (2000), Towards Effective Worker Performance Evaluation: An Important Issue for the New Millennium, Journal of NMIMS Management Review, XII: I, January-June, pp.39-50.

Nickels, Mc Hugh, and Mc Hugh. 1999, Understanding Business, $5^{\text {th }}$ ed, New York: McGraw Hill Co.

Norusis, M.J. (1997), SPSS 7.5 Guide to Data Analysis, New Jersey: Prentice Hall.

Opatha, H.H.D.N.P. (1992), An Assessment of Employee Performance Appraisal Practices of Selected State Corporations in Sri Lanka, Vidyodaya Journal of Social Science, Vol. 6, No. 1\& 2, 113-128.

Opatha, H.H.D.N.P. (2002), Performance Evaluation of Human Resources, $1^{\text {st }}$ ed, Colombo, Sri Lanka: The Author Publication.

Opatha, H.H.D.N.P. (2003), Employee Performance Evaluation Systems: An Evaluative Study of Selected Public Quoted Manufacturing Firms in Sri Lanka, Sabaragamuwa University Journal, Vol.3, No. 1, pp.137-153.

Opatha, H.H.D.N.P. (2003), Research Methods for Human Resource Management, Part I, Colombo, Sri Lanka, Author Publication.

Pettijohn, C.E.S., and Amico, M.D. (2001), 'Characteristics of Performance Appraisals and Their Impact on Sales Force Satisfaction', Human Resource Development Quarterly; San Francisco, Summer, Vol. 12, Issue 2, pp. 127-146. 
Raman D.J. (1998), Improving Human Resource Management, The Executive, Accounting \& Finance Union, Faculty of Business Studies: University of Jaffna, pp. 15-18.

Said, I, Abas, Z, Yosoff, R.Z. and Romle, A.R. (2006), Business Performance Measurement: A Framework for Malaysian Contractors, Conference Proceedings of Third International Conference on Business Management, Faculty of Management Studies and Commerce, University of Sri Jayewardenepura, Sri Lanka, pp. 195-200.

Sekaran, U. (2004), Research Methods for Business, A Skill Building Approach, $4^{\text {th }}$ ed, New York: John Wiley \& Sons (Asia) Pte. Ltd, Singapore. Sibson, R. E. (1925), Human Resources Development, Increasing Employee Productivity, A Division of American Management Associations.

Serasinghe, D.K.S. and Opatha, H.H.D.N.P. (2007), Human Resource Management Practices in Listed Firms in Sri Lanka, Sri Lankan Journal of Human Resource Management, Vol. 1, No.1, pp. 36-52.

Sri Lanka Garments, (2001).

Sri Lanka Garments, (2002).

Thoradeniya, S., Human Resources Development Strategies for Improving Labour Productivity and Total Factor Productivity, Sri Lanka, Labour Gazette, Millenium Issue, The National Journal of Labour Affairs, Ministry of Labour, Labour Secretariat, Colombo, pp. 89-103.

Towers, B. (2000), Human Resource Management : A Manual, $1^{\text {st }}$ ed, New Delhi: Infinity Books.

Tyson, S. and York, A. (2000), Essentials of Human Resource Management, $4^{\text {th }}$ ed, Butterworth Heinemann, Linarce House, Oxford.

Wijewardana, H., Zoysa, A.D., Fonseka, T. and Perera, B. (2000), 'Factors Contributing to the success of Manufacturing Enterprises in Sri Lanka: An Empirical Investigation', Sri Lankan Journal of Management, Vol. 5, No. 1 \& 2, pp. 110 129.

Youndt, M.A., Snell, S.A., Dean, J.W., and Lepak, D.P. (1996), 'Human Resource Management, Manufacturing Strategy, and Firm Performance, Academy of Management Journal, Vol. 39, No. 4, pp. 836 - 86.

\section{Appendix}

\section{An Example of measuring and giving scores on the dimension 'Policies'}

\section{Policies of Performance Appraisal}

There are generally four Employee Performance Evaluation (EPE) policy issues for which an organization needs to answer or clarify in terms of well-defined policies (Glueck, 1979 and Ivancevich, 1998). These are:

1. On whom should EPE be done?

2. When should EPE be done? 
3. Who should do EPE?

4. How often should EPE be done?

Effective policies in respect of the above policies, which are considered as indicators of the dimension of policies of EPE, are as follows:

1. The writing of Glueck(1979) and Schular and Youngblood(1986) suggests that job performance of all permanent and non-permanent employees should be evaluated in order to accomplish as many purposes of EPE as possible. Unnecessary negative attitudes that will create if a part of employees are evaluated are avoided by evaluating all employees. Further this will further to ensure legal defense.

2. General approaches for timing of EPE include Fixed Time approach (evaluating job performance of all employees within a certain period of time-one day or several days), Arbitrary Time approach (evaluating job performance of different employees at different days/times) and Job Cycle approach (evaluating job performance of an employee when he/she finishes all the duties for one time). It is more appropriate to use fixed time approach plus job cycle approach (rather than arbitrary dates approach) in order to have more convenient administration of EPE, more concentration of evaluator on EPE, easier comparison of EPE of different employees and lesser possibility of unfair and inaccurate EPE owing to organizational and environmental causes (such as transfer or promotion of evaluator) and clear starting and ending of work (Glueck, 1979).

3. Arguments of Glueck(1979), Schular and Youngblood(1986), Bernardin and Russel(1993) and observation of Judge and Ferris(1993) suggest that immediate superior of an employee should be allowed to participate in evaluating his or her job performance and, however only the immediate superior is not sufficient. Immediate superior is relatively in a good position to observe the subordinate's job performance closely and he or she has a greater degree of interaction with the subordinate. Use of immediate superior only may encourage a situation where the evaluation is based on not on actual performance but on prejudices. Several sources including immediate superior, immediate superior and immediate superior's superior, several superiors, a committee, an outsider, peers, customers, and self and a combination can be used for job performance evaluation of an employee. As each source has its own advantages and disadvantages use of several sources will enhance the degree of accuracy of EPE by maximizing advantages and minimizing disadvantages (see, Ivancevich, 1998).

4. Companies that conduct multiple EPE had better results in terms of total shareholder return on equity, sales growth and cash flow (Martinez, 1997). In the current business climate, to consider monitoring performance often may be well for all firms (Mondy et al, 1999). Research has shown that many employees believe performance feedback should be given more frequently than once or twice a year (Bernarding and Christopher, 1997 as in Anthony and et al, 1999) and, thus, suggesting doing EPE frequently. To do EPE often or too frequent is not realistic due to time and other constraints. To conduct formal PE at least twice per year seems to be more 
appropriate owing to lesser probability of occurring recency effect and greater opportunity of giving feedback.

Degree of soundness of EPE policies being followed by the selected cases was rated on a 5-point scale based on the above effective policies. Scores of 5,4,3,2, and 1 were given depending on the varying degrees of soundness of EPE policies. Soundness of on whom was measured by giving 5 for 'on every employee'; 4 for ' on permanent employees only'; 3 for 'on managerial employees only'; 2 for 'on every employee except minor staff' and; 1 for 'on other specific category only'. Regarding second policy issue, 5 was given for fixed time and job cycle approaches, 4 was given for job cycle only, 3 for fixed time only, 2 for arbitrary time only and 1 for no clear policy. Third policy issue (soundness of who) was rated on a 5 -point scale $(5=$ combination of more than three sources; $4=$ combination of three sources; $3=$ combination of two sources; $2=$ immediate supervisor only; and 1= any other source only). In respect of fourth policy issue, 5 was given for monthly/fourth-monthly (for every two months), 4 for quarterly, 3 for semiannually, 2 for annually, and 1 for more than one year.

Source: Opatha (2003) 